\title{
Promotional effects of Sb on Pd-based catalysts for the direct synthesis of hydrogen peroxide at ambient pressure
}

\author{
Doudou Ding a, Xingyan Xu a, Pengfei Tiana a, Xianglin Liu a, Jing Xu a,*, Yi-Fan Han a,b,\# \\ a State Key Laboratory of Chemical Engineering, East China University of Science and Technology, Shanghai 200237, China \\ ${ }^{\mathrm{b}}$ Research Center of Heterogeneous Catalysis and Engineering Science, School of Chemical Engineering and Energy, Zhengzhou University, Zhengzhou \\ 450001, Henan, China
}

\section{A R T I C L E I N F O}

\section{Article history:}

Received 30 November 2017

Accepted 10 January 2018

Published 5 April 2018

\section{Keywords:}

Bimetallic catalyst

Hydrogen peroxide

Palladium

Antimony

Direct synthesis

\begin{abstract}
A B S T R A C T
$\mathrm{TiO}_{2}$-supported Pd-Sb bimetallic catalysts were prepared and evaluated for the direct synthesis of $\mathrm{H}_{2} \mathrm{O}_{2}$ at ambient pressure. The addition of $\mathrm{Sb}$ to Pd significantly enhanced catalytic performance, and a $\mathrm{Pd}_{50} \mathrm{Sb}$ catalyst showed the greatest selectivity of up to $73 \%$. Sb promoted the dispersion of Pd on $\mathrm{TiO}_{2}$, as evidenced by transmission electron microscopy and X-ray diffraction. X-ray photoelectron spectroscopy indicated that the oxidation of $\mathrm{Pd}$ was suppressed by $\mathrm{Sb}$. In addition, $\mathrm{Sb}_{2} \mathrm{O}_{3}$ layers were formed and partially wrapped the surfaces of Pd catalysts, thus suppressing the activation of $\mathrm{H}_{2}$ and subsequent hydrogenation of $\mathrm{H}_{2} \mathrm{O}_{2}$. In situ diffuse reflection infrared Fourier transform spectroscopy for $\mathrm{CO}$ adsorption suggested that $\mathrm{Sb}$ homogenously located on the surface of Pd-Sb catalysts and isolated contiguous Pd sites, resulting in the rise of the ratio of Pd monomer sites that are favorable for $\mathrm{H}_{2} \mathrm{O}_{2}$ formation. As a result, the $\mathrm{Sb}$ modified Pd surfaces significantly enhanced the non-dissociative activation of $\mathrm{O}_{2}$ and $\mathrm{H}_{2} \mathrm{O}_{2}$ selectivity.
\end{abstract}

(C) 2018, Dalian Institute of Chemical Physics, Chinese Academy of Sciences. Published by Elsevier B.V. All rights reserved.

\section{Introduction}

Hydrogen peroxide $\left(\mathrm{H}_{2} \mathrm{O}_{2}\right)$, which is an environmental benign oxidant, is widely applied in the textile, pulp/paper bleaching, waste water treatment, and pharmaceutical industries [1]. Currently, over three million metric tons of $\mathrm{H}_{2} \mathrm{O}_{2}$ are produced annually via the anthraquinone process, which involves sequential hydrogenation and oxidation of anthraquinone $[1,2]$. However, there are concerns about the carbon efficiency of the process, not least of which is the unselective hydrogenation of anthraquinone that requires replenishment during the cycle. Moreover, the process inherently requires large capital and operating costs, because of the ener- gy-intensive separation, concentration, and transportation of $\mathrm{H}_{2} \mathrm{O}_{2}$ [3]. From an economic and environmental point of view, the direct synthesis of $\mathrm{H}_{2} \mathrm{O}_{2}$ from $\mathrm{H}_{2}$ and $\mathrm{O}_{2}$ over a Pd-based catalyst is a promising, desirable, and atom-efficient route that provides an alternative to the current process. Direct synthesis avoids the use of expensive anthraquinone, the production of waste, and the complexity of purification. What is more, the coupling of direct, on-line $\mathrm{H}_{2} \mathrm{O}_{2}$ production with downstream oxidation is highly desirable in that it produces value-added products by shortening the supply chain [4-7].

Although direct synthesis has advantages over the existing process, its industrial implementation has been hindered by the limited selectivity and stability of supported Pd nanoparti-

\footnotetext{
* Corresponding author. Tel: +86-21-64251938; Fax: +86-21-64251928; E-mail: xujing@ecust.edu.cn

\# Corresponding author. E-mail: yifanhan@ecust.edu.cn

This work was supported by the National Natural Science Foundation of China (91534127, U1463205), the Innovation Scientists and Technicians Troop Construction Projects of Henan Province, and the Chinese Education Ministry 111 Project (B08021).

DOI: 10.1016/S1872-2067(18)63031-1 | http://www.sciencedirect.com/science/journal/18722067 | Chin. J. Catal., Vol. 39, No. 4, April 2018
} 
cles (NPs), which are the most active known catalysts [8]. It is known that apart from facilitating the selective oxidation of $\mathrm{H}_{2}$ to $\mathrm{H}_{2} \mathrm{O}_{2}$, monometallic $\mathrm{Pd}$ catalysts also promote the non-selective oxidation of $\mathrm{H}_{2}$ to water and the hydrogenation of $\mathrm{H}_{2} \mathrm{O}_{2}$. Several strategies have been employed to overcome this limitation by modifying the structure of Pd NPs: (1) tuning the Pd ensembles with supports [9-13], (2) altering their surface properties with ligands [14], and (3) alloying Pd with a second metal (e.g., Pt, Au, Sn, Zn) [15-19]. Pd-Au and Pd-Sn catalysts are the most selective catalysts operating at high pressure (4.0 $\mathrm{MPa}$ ) to date. Our previous study of $\mathrm{Pd}-\mathrm{Au} / \mathrm{TiO}_{2}$ catalysts showed that $\mathrm{Pd}$ monomers surrounded by $\mathrm{Au}$ atoms can be primary active sites for $\mathrm{H}_{2} \mathrm{O}_{2}$ formation [17], in good agreement with theoretical calculations that $\mathrm{O}-\mathrm{O}$ bond scission is suppressed over Pd-Au sites [20]. Maity et al. [21] demonstrated that bimetallic Ni-Pd catalysts in the presence of halide ions showed three times greater activities than monometallic Pd catalysts. In our recent work, initial $\mathrm{H}_{2} \mathrm{O}_{2}$ selectivities of more than $90 \%$ were obtained over $\mathrm{Pd}-\mathrm{Te} / \mathrm{TiO}_{2}$ and $\mathrm{Pd} / \mathrm{HAp}$ catalysts at $283 \mathrm{~K}, 0.1 \mathrm{MPa}$. Even so, the activities and stability of these catalysts do not meet the requirements of commercial production [22,23].

$\mathrm{Sb}$ has been shown to improve the performance of Pd catalysts [24] and can be alloyed with Pd [25,26]. We report, herein, the promotional effects of $\mathrm{Sb}$ on $\mathrm{Pd}$ catalysts for $\mathrm{H}_{2} \mathrm{O}_{2}$ formation. A series of $\mathrm{Pd}-\mathrm{Sb} / \mathrm{TiO}_{2}$ catalysts with different $\mathrm{Pd} / \mathrm{Sb}$ ratios were prepared and tested for direct $\mathrm{H}_{2} \mathrm{O}_{2}$ synthesis under ambient conditions. The nature of the active sites was examined thoroughly, and deep insight into the structure-performance behavior of the catalysts was obtained by multiple methods of characterization including transmission electron microscopy (TEM), X-ray diffraction (XRD), X-ray photoelectron spectroscopy (XPS), in situ diffuse reflection infrared Fourier transform spectroscopy for CO adsorption (CO-DRIFTS), and temperature-programmed desorption of $\mathrm{H}_{2}$ and $\mathrm{O}_{2}\left(\mathrm{H}_{2} / \mathrm{O}_{2}-\mathrm{TPD}\right)$.

\section{Experimental}

\subsection{Catalyst preparation}

Monometallic Pd and bimetallic Pd-Sb catalysts were prepared by an incipient wetness impregnating method as described in a previous study [27]. An aqueous solution of $\mathrm{H}_{2} \mathrm{PdCl}_{4}$ (Sigma-Aldrich) and $\mathrm{SbCl}_{3}$ (Aladdin, 99.9\%) were used as the precursor. $\mathrm{TiO}_{2}$ (Degussa $\mathrm{P} 25,50 \pm 15 \mathrm{~m}^{2} / \mathrm{g}$ ) was adopted as the support. Pd-Sb catalysts with $\mathrm{Sb} / \mathrm{Pd}$ atomic ratios of $0,1 / 80,1 / 50,1 / 20$, and $1 / 2$ were prepared. Each catalyst had a $3 \mathrm{wt} \% \mathrm{Pd}$ loading. Prior to reaction, all catalysts were calcined in static air at $773 \mathrm{~K}$ for $2 \mathrm{~h}$ and then reduced at $573 \mathrm{~K}$ in a 1:2 $\mathrm{H}_{2}: \mathrm{N}_{2}$ flow at $75 \mathrm{~mL} / \mathrm{min}$ for $2 \mathrm{~h}$ at a ramp rate of 5 $\mathrm{K} / \mathrm{min}$. The resulting catalysts are denoted as $\mathrm{Pd}_{x} \mathrm{Sb}$, where $x$ is the molar ratio of $\mathrm{Pd}$ to $\mathrm{Sb}$.

\subsection{Catalyst characterization}

TEM measurements were performed on a JEOL JEM 2010F electron microscope at an operating voltage of $200 \mathrm{kV}$. The catalysts were ultrasonically suspended in ethanol. One drop of this slurry was deposited on a carbon-coated copper grid. The liquid phase was evaporated before loading the grid into the microscope. The size distribution of each sample was derived from the analysis of over 300 particles.

XRD powder patterns at ambient conditions were recorded using a Rigaku D/max 2550 diffractometer with an accelerator voltage of $40 \mathrm{kV}$ and a detector current of $100 \mathrm{~mA}$. Cu- $K_{\alpha}$ radiation was used for continuous scanning with a step-size of $0.02^{\circ}$ over a $2 \theta$ range of $10^{\circ}-80^{\circ}$ with a scan speed of $4^{\circ} / \mathrm{min}$.

XPS analysis was performed on a Thermo ESCALAB 250Xi spectrometer using a monochromatic Al- $K_{\alpha}$ radiation source (1486.6 eV, pass energy $20.0 \mathrm{eV}$ ). The base pressure of the instrument was about $1 \times 10^{-9}$ Torr. Binding energies (BEs) were calibrated using the $\mathrm{C} 1 s$ peak at $284.8 \mathrm{eV}$ as a reference. The $\mathrm{Pd} 3 d$ peaks were fitted after Shirley background subtraction; the Pd $3 d$ orbitals were described by two features in each state. A branching ratio of 1.5 for $3 d_{5 / 2}: 3 d_{3 / 2}$ and the full width at half maximum (FWHM) of the Pd $3 d$ peaks were held constant. The $3 d_{3 / 2}$ and $3 d_{5 / 2}$ peaks of $\mathrm{Sb}$ also were measured with the latter being overlapped by the $01 s$ transition. Linear background subtraction was used to fit the $\mathrm{Sb} 3 d$ peaks. It is evident from the shape of the Sb $3 d_{5 / 2}$ transitions that these BEs and those of $01 s$ are very close making deconvolution of the individual contributions difficult. Thus, we chose to constrain only the peak position based on the energy difference $(9.35 \mathrm{eV})$ of the $\mathrm{Sb} 3 d$ doublet. The $\mathrm{Pd} 3 d, \mathrm{Sb} 3 d$, and $\mathrm{O} 1 s$ spectral features were fitted using a sum of Gaussian-Lorentzian distributions (SGL (20)).

In situ CO-DRIFTS was recorded on a Perkin-Elmer Spectrum 100 FT-IR spectrometer equipped with a reaction cell (modified Harricks Model HV-DR2) that allowed gas to flow continuously through the catalyst bed (ca. $0.1 \mathrm{~g}$ ) during spectra acquisition. Before adsorption, the sample was reduced in situ and then cooled to $283 \mathrm{~K}$ in pure Ar. CO gas was introduced into the system for $30 \mathrm{~min}$. The spectra were collected at $4 \mathrm{~cm}^{-1}$ resolution. The bridge- to linear-bound ratios reported here do not take into account the differences in extinction coefficient between adsorption sites. Therefore, the bridge- to linear-bound ratio does not represent quantitative coverages, but rather the qualitative differences between catalysts.

$\mathrm{H}_{2} / \mathrm{O}_{2}$-TPD experiments were performed using a U-tube connected to a GC-QMS (HPR-20, Hiden Analytical Ltd.), where masses of $m / e=2\left(\mathrm{H}_{2}\right), 18\left(\mathrm{H}_{2} \mathrm{O}\right), 32\left(\mathrm{O}_{2}\right)$, and $40(\mathrm{Ar})$ were monitored. Prior to the adsorption, the catalysts were pretreated in static air at $773 \mathrm{~K}$ for $2 \mathrm{~h}$, in $\mathrm{H}_{2} / \mathrm{Ar}$ at $573 \mathrm{~K}$ for $2 \mathrm{~h}$, and then cooled in ultrapure $\mathrm{Ar} . \mathrm{H}_{2} / \mathrm{O}_{2}$ adsorbate $(20 \mathrm{~mL} / \mathrm{min}$, $30 \mathrm{~min}$ ) was introduced into the system at $283 \mathrm{~K}$. The system was purged with $\mathrm{Ar}(40 \mathrm{~mL} / \mathrm{min})$ until the $\mathrm{H}_{2} / \mathrm{O}_{2}$ signal reached a constant value. The temperature was ramped from 283 to $1073 \mathrm{~K}$ at a rate of $20 \mathrm{~K} / \mathrm{min}$ in $\operatorname{Ar}(40 \mathrm{~mL} / \mathrm{min})$.

\subsection{Catalyst testing}

$\mathrm{H}_{2} \mathrm{O}_{2}$ synthesis and degradation activity were evaluated using a modified micro-triphase-semi-batch reactor at $283 \mathrm{~K}$ and 
atmospheric pressure. The reactor was charged with catalyst $(0.05 \mathrm{~g})$ and $60 \mathrm{~mL}$ of ethanol and $0.38 \mathrm{~mL}$ of concentrated $\mathrm{H}_{2} \mathrm{SO}_{4}$ as reaction solvent to test the $\mathrm{H}_{2} \mathrm{O}_{2}$ synthesis. The reagent gases $\left(15 \mathrm{vol} \% \mathrm{H}_{2}, 60\right.$ vol\% $\mathrm{O}_{2}, 25 \mathrm{vol} \% \mathrm{~N}_{2}, 60 \mathrm{~mL} / \mathrm{min}$ total flowrate) were introduced to the reactor through a premixer and fine glass frit in sequence with Teflon-rotor magnetic stirring at $1000 \mathrm{r} / \mathrm{min} . \mathrm{H}_{2}$ conversion was analyzed by gas chromatography, and $\mathrm{H}_{2} \mathrm{O}_{2}$ production was determined by UV/vis spectrophotometry after complexation with a Ti$\mathrm{OSO}_{4} / \mathrm{H}_{2} \mathrm{SO}_{4}$ reagent. $\mathrm{H}_{2} \mathrm{O}_{2}$ selectivity $\left(\mathrm{S}_{\mathrm{H}_{2} \mathrm{O}_{2}}\right)$ was determined from the rate of $\mathrm{H}_{2} \mathrm{O}_{2}$ formation and the rate of $\mathrm{H}_{2}$ conversion using the equation

$$
S_{\mathrm{H}_{2} \mathrm{O}_{2}}=\frac{\text { Rate of } \left.\mathrm{H}_{2} \mathrm{O}_{2} \text { formation ( } \mathrm{mol} / \mathrm{min}\right)}{\text { Rate of } \left.\mathrm{H}_{2} \text { conversion ( } \mathrm{mol} / \mathrm{min}\right)} \times 100 \%
$$

$\mathrm{H}_{2} \mathrm{O}_{2}$ decomposition and hydrogenation experiments were carried out in a manner similar to the $\mathrm{H}_{2} \mathrm{O}_{2}$ synthesis, but in the absence of $\mathrm{O}_{2}$. The initial $\mathrm{H}_{2} \mathrm{O}_{2}$ concentration was $0.3 \mathrm{wt} \%$. The reaction was conducted for $1 \mathrm{~h}$ with the concentration of $\mathrm{H}_{2} \mathrm{O}_{2}$ determined every $10 \mathrm{~min}$.

\section{Results and discussion}

\subsection{Catalytic performance}

The performance of the Pd-Sb catalysts is summarized in Table 1 and compared with those of typical catalysts reported in the literature (Table S1). The synthesis of $\mathrm{H}_{2} \mathrm{O}_{2}$ and its hydrogenation/decomposition reactions take place simultaneously. Thus, productivity is the sum of all these processes [28]. A $\mathrm{H}_{2}$ conversion of $29.5 \%$ and $\mathrm{a}_{2} \mathrm{O}_{2}$ selectivity of $54 \%$ was observed with monometallic Pd. Upon addition of Sb, selectivity increases to $68 \%$ for $\mathrm{Pd}_{80} \mathrm{Sb}$. A uniquely high $\mathrm{H}_{2} \mathrm{O}_{2}$ selectivity of $73 \%$ corresponding to a $\mathrm{H}_{2} \mathrm{O}_{2}$ productivity of $1552 \mathrm{~mol}$ $\mathrm{H}_{2} \mathrm{O}_{2} / \mathrm{kg}$ Pd $/ \mathrm{h}$ was found for $\mathrm{Pd}_{50} \mathrm{Sb}$. The activities and selectivities of the catalysts decline at $\mathrm{Pd} / \mathrm{Sb}=20$, and the catalyst with a $\mathrm{Pd} / \mathrm{Sb}$ ratio of 2 is inactive.

To understand the promotional effects of $\mathrm{Sb}$, the $\mathrm{H}_{2} \mathrm{O}_{2}$ decomposition and hydrogenation side reactions must be taken into account. For $\mathrm{H}_{2} \mathrm{O}_{2}$ decomposition, $\mathrm{H}_{2} \mathrm{O}_{2}$ consumption was negligible over all catalysts under $\mathrm{N}_{2}$ flow. In contrast, $\mathrm{H}_{2} \mathrm{O}_{2}$ conversion was observed under $\mathrm{H}_{2}$ flow. We conclude that $\mathrm{H}_{2} \mathrm{O}_{2}$ hydrogenation is the main pathway for subsequent $\mathrm{H}_{2} \mathrm{O}_{2}$ con-

Table 1

Performance of $\mathrm{Pd}-\mathrm{Sb} / \mathrm{TiO}_{2}$ catalysts for $\mathrm{H}_{2} \mathrm{O}_{2}$ synthesis.

\begin{tabular}{|c|c|c|c|c|}
\hline Catalyst & $\begin{array}{c}\mathrm{H}_{2} \\
\text { conversion } \\
(\%)\end{array}$ & $\begin{array}{c}\mathrm{H}_{2} \mathrm{O}_{2} \\
\text { selectivity } \\
(\%)\end{array}$ & $\begin{array}{c}\mathrm{H}_{2} \mathrm{O}_{2} \\
\text { productivity } \\
(\mathrm{mol} \\
\left.\mathrm{H}_{2} \mathrm{O}_{2} / \mathrm{kg}_{\text {Pd }} / \mathrm{h}\right)\end{array}$ & $\begin{array}{c}\mathrm{H}_{2} \mathrm{O}_{2} \\
\text { hydrogenation } \\
\text { rate }(\mathrm{mol} \\
\left.\mathrm{H}_{2} \mathrm{O}_{2} / \mathrm{kg}_{\mathrm{Pd}} / \mathrm{h}\right)\end{array}$ \\
\hline $\mathrm{Pd}_{2} \mathrm{Sb}$ & n.d. & n.d. & n.d. & 1223 \\
\hline $\mathrm{Pd}_{20} \mathrm{Sb}$ & 13.8 & 57 & 1256 & 2018 \\
\hline $\mathrm{Pd}_{50} \mathrm{Sb}$ & 13.9 & 73 & 1552 & 2158 \\
\hline $\mathrm{Pd}_{80} \mathrm{Sb}$ & 19.3 & 68 & 2002 & 2307 \\
\hline $\mathrm{Pd}$ & 29.5 & 54 & 2541 & 2678 \\
\hline
\end{tabular}

Reaction conditions: $60 \mathrm{~mL}$ solvent (ethanol $/ \mathrm{H}_{2} \mathrm{SO}_{4}$ ), total gas flow rate of $60 \mathrm{~mL} / \mathrm{min}\left(\mathrm{H}_{2}: \mathrm{O}_{2}: \mathrm{N}_{2}=9: 36: 15 \mathrm{vol} / \mathrm{vol} / \mathrm{vol}\right), 50 \mathrm{mg}$ catalyst, $0.1 \mathrm{MPa}$, $283 \mathrm{~K}, 1 / 6 \mathrm{~h}$, stirring rate $=1000 \mathrm{r} / \mathrm{min}$. n.d.: Not detected. version, which lowers the selectivity (Fig. 1). Monometallic Pd showed the greatest $\mathrm{H}_{2} \mathrm{O}_{2}$ hydrogenation activity with a rate of $2678 \mathrm{~mol} \mathrm{H}_{2} \mathrm{O}_{2} / \mathrm{kgPd} / \mathrm{h}$ (Table 1). The hydrogenation rate declined with increasing $\mathrm{Sb}$ concentration. $\mathrm{Pd}_{2} \mathrm{Sb}$ exhibited the lowest hydrogenation activity. These results indicate that addition of $\mathrm{Sb}$ blocks $\mathrm{H}_{2} \mathrm{O}_{2}$ hydrogenation. However, $\mathrm{Pd}_{2} \mathrm{Sb}$ showed little $\mathrm{H}_{2}$ conversion activity despite its low $\mathrm{H}_{2} \mathrm{O}_{2}$ hydrogenation activity. This might result from the absence of active sites on the catalyst surface at large Sb loading. The dependence of catalytic performance on $\mathrm{Sb}$ loading suggests that variation of the $\mathrm{Pd} / \mathrm{Sb}$ atomic ratio finely tunes the electronic and geometric structures of Pd-Sb catalysts. To unveil the mechanism of active sites formation, the catalysts were systematically characterized.

\subsection{Catalytic characterization}

\subsubsection{Catalyst morphology}

Fig. 2 displays typical TEM images and particle size distributions of the fresh catalysts. Compared to $\mathrm{Pd}_{50} \mathrm{Sb}$, monometallic Pd exhibits a broad particle size distribution and an average size of ca. $3.2 \mathrm{~nm}$ (Fig. 2(c)). The lattice fringes with a 0.24-nm spacing corresponding to the $\mathrm{Pd}(111)$ plane are clearly visible in the HRTEM images. The mean particle diameter decreases to ca. $1.8 \mathrm{~nm}$ (Fig. 2(d)) for $\mathrm{Pd}_{50} \mathrm{Sb}$, suggesting that the addition of $\mathrm{Sb}$ significantly promotes dispersion of the Pd particles.

XRD patterns (Fig. 3) show that $\mathrm{TiO}_{2}$ (Degussa P25) is composed of two phases, anatase and rutile, even after loading Pd. Almost no crystalline Pd was detected, except that a small peak at $40.4^{\circ}$, which was assigned to the $\operatorname{Pd}(111)$ plane, was observed for some catalysts. When the Pd:Sb ratio decreased to $2: 1$, the $40.4^{\circ}$ peak vanished. The results indicate that $\mathrm{Pd}-\mathrm{Sb}$ catalysts comprise mainly small metal particles $(<4.0 \mathrm{~nm})$, which are beyond the detection limit of XRD. The conclusion is consistent with TEM results [29].

\subsubsection{Electronic structure}

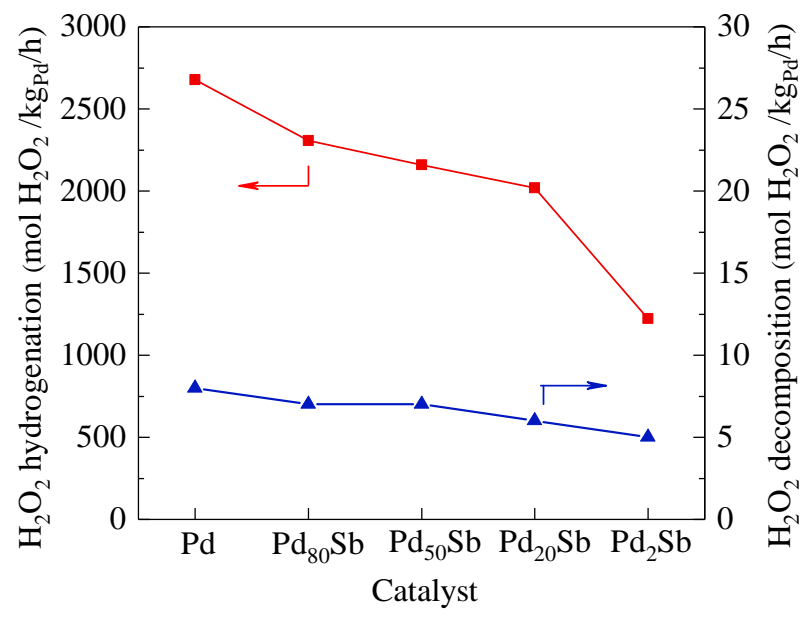

Fig. 1. $\mathrm{H}_{2} \mathrm{O}_{2}$ hydrogenation and decompositionover $\mathrm{Pd}-\mathrm{Sb} / \mathrm{TiO}_{2}$ catalysts. ( $\boldsymbol{\bullet} \mathrm{H}_{2} \mathrm{O}_{2}$ hydrogenation, ( $\left.\boldsymbol{\Delta}\right) \mathrm{H}_{2} \mathrm{O}_{2}$ decomposition. Reaction conditions: total gas flow rate $=60 \mathrm{~mL} / \mathrm{min}\left(\mathrm{H}_{2}: \mathrm{N}_{2}=9: 51\right.$ (vol/vol) for $\mathrm{H}_{2} \mathrm{O}_{2}$ hydrogenation and total $\mathrm{N}_{2}$ for $\mathrm{H}_{2} \mathrm{O}_{2}$ decomposition), ethanol/ $\mathrm{H}_{2} \mathrm{SO}_{4}$ solvent, $50 \mathrm{mg}$ catalyst, $283 \mathrm{~K}, 0.1 \mathrm{MPa}, 1 \mathrm{~h}$, stirring rate $=1000 \mathrm{r} / \mathrm{min}$. 

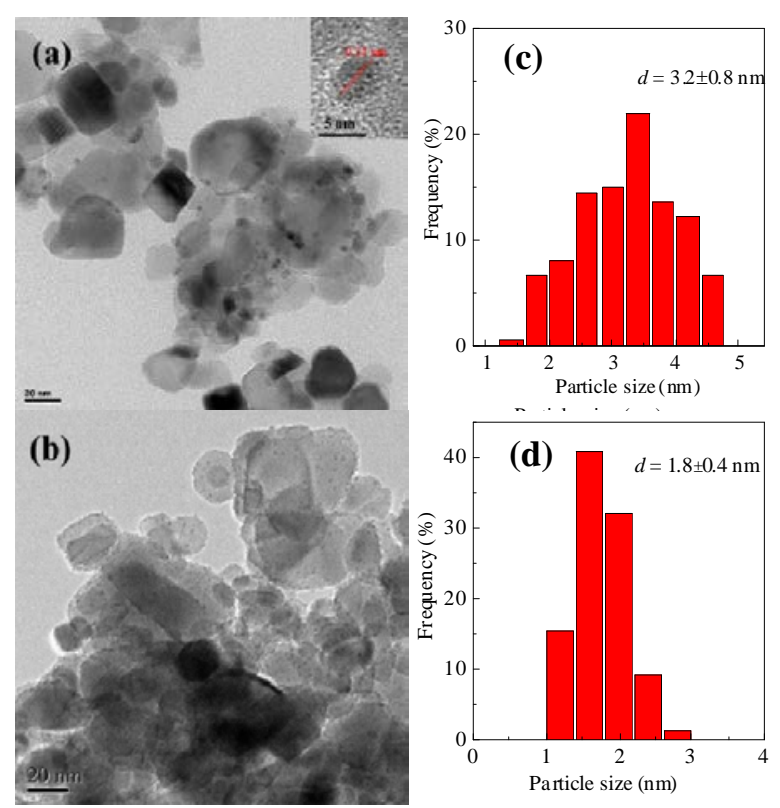

Fig. 2. TEM images and particle size distributions of fresh Pd (a, c) and $\mathrm{Pd}_{50} \mathrm{Sb}(\mathrm{b}, \mathrm{d})$ catalysts.

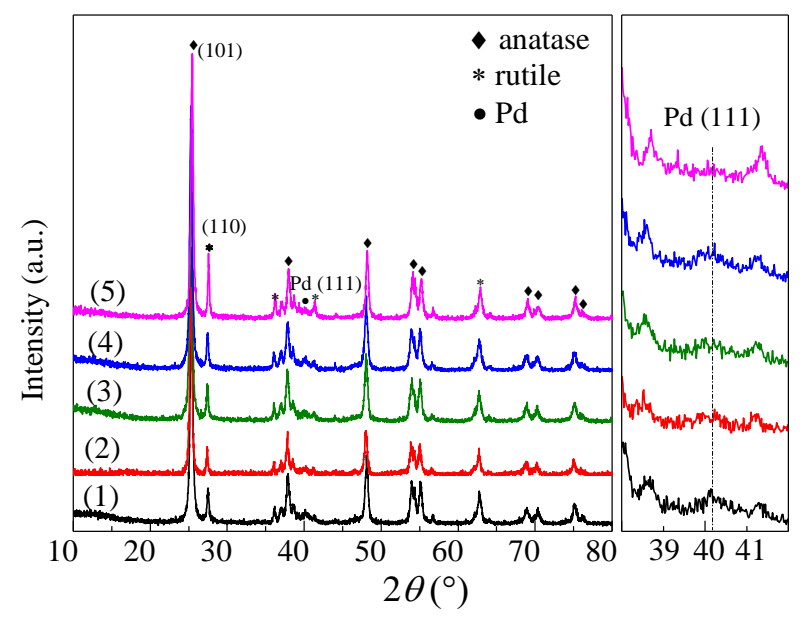

Fig. 3. XRD patterns of fresh catalysts. (1) Pd, (2) $\mathrm{Pd}_{80} \mathrm{Sb}$, (3) $\mathrm{Pd}_{50} \mathrm{Sb}$, (4) $\mathrm{Pd}_{20} \mathrm{Sb}$, (5) $\mathrm{Pd}_{2} \mathrm{Sb}$.

The chemical nature of the catalyst surface, in particular the $\mathrm{Pd}^{2+} / \mathrm{Pd}^{0}$ ratio, is crucial to $\mathrm{H}_{2} \mathrm{O}_{2}$ selectivity $[11,30]$. Thus, XPS analysis was performed to examine the electronic interactions between $\mathrm{Pd}$ and $\mathrm{Sb}$ and the valence state of Pd surface species. The Pd $3 d$ core-level spectra for all catalysts are displayed in Fig. 4, and results are summarized in Table 2 . Peaks with bind-

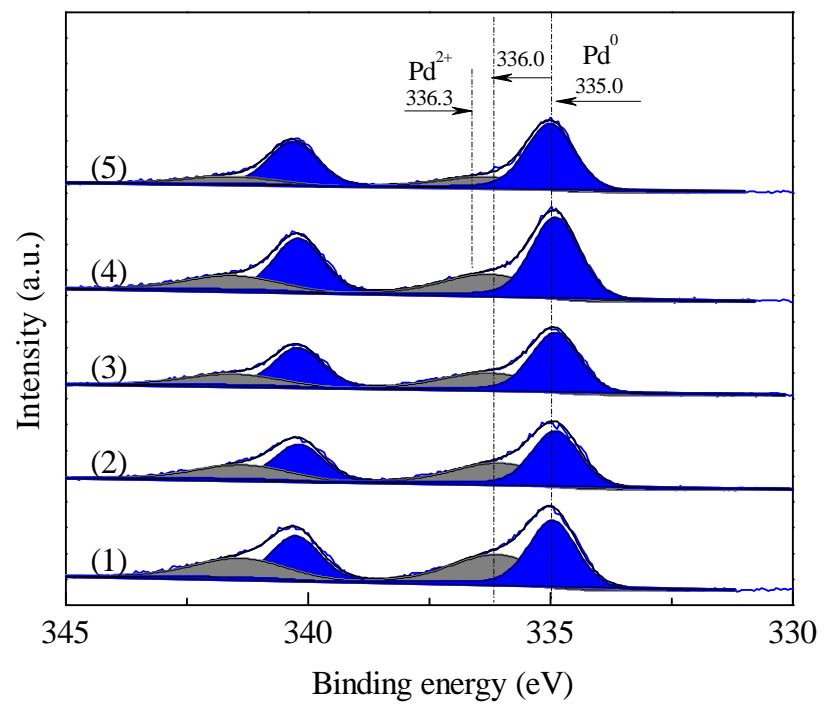

Fig. 4. Fitted Pd 3d XPS spectra of fresh catalysts. (1) Pd, (2) Pd ${ }_{80} \mathrm{Sb}$, (3) $\mathrm{Pd}_{50} \mathrm{Sb}$, (4) $\mathrm{Pd}_{20} \mathrm{Sb}$, (5) $\mathrm{Pd}_{2} \mathrm{Sb}$.

ing energies of 334.9 and $340.3 \mathrm{eV}$ are attributed to $\mathrm{Pd}^{0} 3 d_{5 / 2}$ and $3 d_{3 / 2}$, respectively [31,32], while those at 341.3 and 336.0 $\mathrm{eV}$ are assigned to $\mathrm{Pd}^{2+} 3 d_{5 / 2}$ and $3 d_{3 / 2}$ [33,34]. $\mathrm{Pd}^{0}$ and $\mathrm{Pd}^{2+}$ were detected in all catalysts, and the $\mathrm{Pd}^{0} / \mathrm{Pd}^{2+}$ ratio increased from 58.4/41.6 in Pd to 77.1/22.9 in $\mathrm{Pd}_{2} \mathrm{Sb}$. Thus, addition of $\mathrm{Sb}$ inhibited the oxidation of metallic Pd. Our previous study detected only metallic $\mathrm{Pd}^{0}$ for $\mathrm{Pd} / \mathrm{SiO}_{2}$ [35], which indicates that formation of $\mathrm{Pd}^{2+}$ species might result from interaction between $\mathrm{Pd}$ particles and $\mathrm{TiO}_{2}[17,27]$.

Chemical states in the Sb $3 d$ XPS spectrum (Fig. 5(a)) are difficult to identify by deconvoluting the individual contributions due to overlap of the $\mathrm{Sb} 3 d_{5 / 2}$ and $01 s$ core levels. Because of the low $\mathrm{Sb}$ concentration, almost no $\mathrm{Sb}$ peaks are observed apart from a distinguishable one at $539.5 \mathrm{eV}$ for $\mathrm{Pd}_{2} \mathrm{Sb}$. The 539.5 and $530.1 \mathrm{eV}$ peaks are attributed to $\mathrm{Sb}^{3+} 3 d_{3 / 2}$ and $3 d_{5 / 2}$ (Fig. 5(b)), respectively. The atomic ratio of $\mathrm{Sb} / \mathrm{Pd}$ on the surface of $\mathrm{Pd}_{2} \mathrm{Sb}$ is $9 / 10$ based on the relative sensitivity factor (RSF) (Pd: 39.787, Sb: 19.353) and their signal intensity, which is markedly greater than the bulk $\mathrm{Sb} / \mathrm{Pd}$ ratio in the catalyst. This suggests that an $\mathrm{Sb}_{2} \mathrm{O}_{3}$ layer forms on and covers the $\mathrm{Pd}$ surface of Pd-Sb catalysts with a large Sb content [36,37]. Because of the encapsulating $\mathrm{Sb}_{2} \mathrm{O}_{3}$ layer on the catalyst surface, $\mathrm{H}_{2}$ and $\mathrm{O}_{2}$ activation is hindered rendering $\mathrm{Pd}_{2} \mathrm{Sb}$ inert in this reaction. A decrease in exposed $\mathrm{Pd}$ area also was detected by CO pulse chemisorption (Table S2), which further suggests the encapsulation of Pd particles by Sb. BEs of 531.7, 530.3, and $529.8 \mathrm{eV}$ in the $01 s$ core-level spectra are attributed, respec-

Table 2

Quantative XPS data for surface Pd atoms.

\begin{tabular}{|c|c|c|c|c|c|c|}
\hline \multirow{2}{*}{ Catalyst } & \multicolumn{2}{|c|}{$\operatorname{Pd} 3 d_{3 / 2}(\mathrm{eV})$} & \multicolumn{2}{|c|}{$\operatorname{Pd} 3 d_{5 / 2}(\mathrm{eV})$} & \multirow{2}{*}{$\mathrm{Pd}^{0}(\%)$} & \multirow{2}{*}{$\mathrm{Pd}^{2+}(\%)$} \\
\hline & $\mathrm{Pd}^{2+}$ & $\mathrm{Pd}^{0}$ & $\mathrm{Pd}^{2+}$ & $\mathrm{Pd}^{0}$ & & \\
\hline $\mathrm{Pd}_{2} \mathrm{Sb}$ & 341.6 & 340.3 & 336.3 & 335.0 & 77.14 & 22.86 \\
\hline $\mathrm{Pd}_{20} \mathrm{Sb}$ & 341.6 & 340.2 & 336.3 & 334.9 & 67.47 & 32.53 \\
\hline $\mathrm{Pd}_{50} \mathrm{Sb}$ & 341.6 & 340.2 & 336.3 & 334.9 & 65.58 & 34.32 \\
\hline $\mathrm{Pd}_{80} \mathrm{Sb}$ & 341.6 & 340.2 & 336.3 & 334.9 & 58.36 & 41.64 \\
\hline $\mathrm{Pd}$ & 341.3 & 340.3 & 336.0 & 335.0 & 54.92 & 45.08 \\
\hline
\end{tabular}



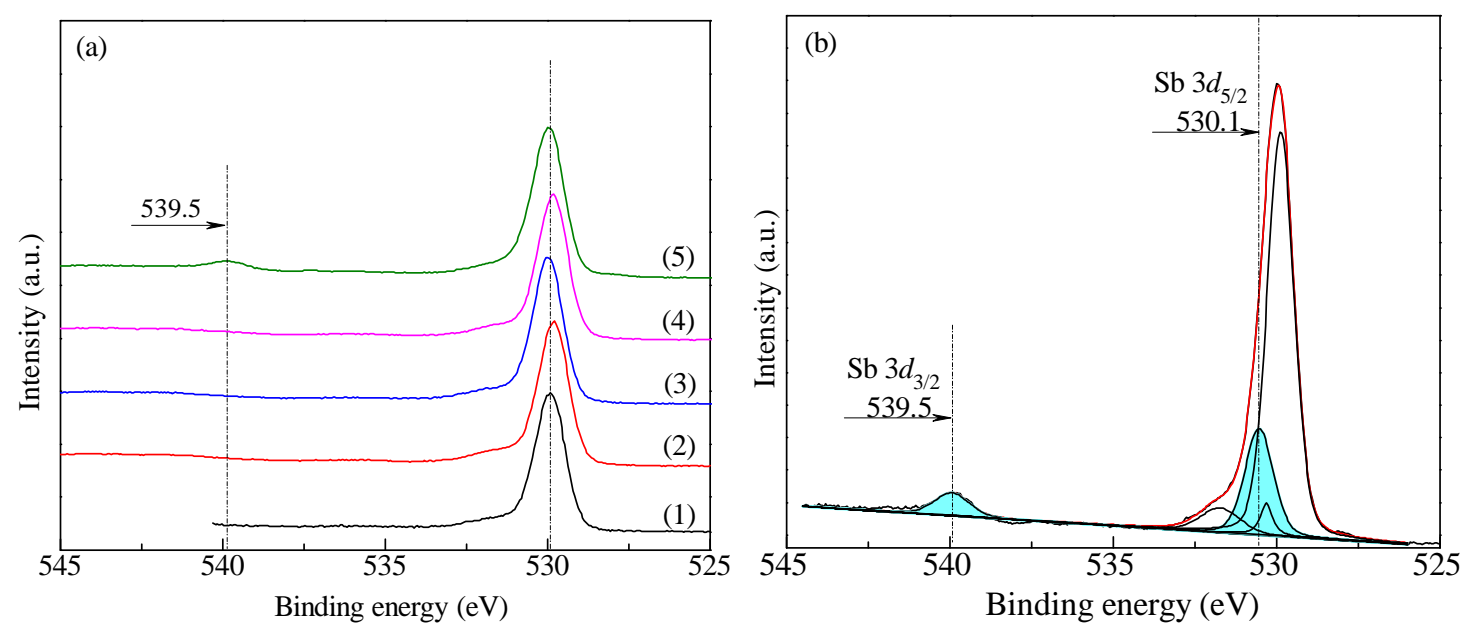

Fig. 5. (a) Sb $3 d$ and $01 s$ XPS spectra of fresh catalysts. (1) Pd, (2) $\mathrm{Pd}_{80} \mathrm{Sb}$, (3) $\mathrm{Pd}_{50} \mathrm{Sb}$, (4) $\mathrm{Pd}_{20} \mathrm{Sb}$, (5) Pd $\mathrm{Pd}_{2} \mathrm{Sb}$. (b) Fitted Sb $3 d \mathrm{XPS}$ spectra of fresh Pd $\mathrm{Pd}_{2} \mathrm{Sb}$.

tively to the following oxygen species: (1) the oxygen of surface hydroxyl groups or carbonate species formed by exposing the sample to air [38], (2) the lattice oxygen of $\mathrm{TiO}_{2}$, and (3) oxygen adsorbed on the surface of $\mathrm{PdO} / \mathrm{SbO}_{x}$ particles [39].

\subsubsection{CO-DRIFTS}

The spectra of adsorbed CO (Fig. 6) show absorption bands of CO ( $v(\mathrm{CO})$ ) at 2078, 1982, and $1923 \mathrm{~cm}^{-1}$ for the monometallic Pd catalyst $[40,41]$. The peak at $2078 \mathrm{~cm}^{-1}$ represents linearly bonded $\mathrm{CO}$ (Pd-CO) at the small population of Pd atoms that are located at corner or edge positions on Pd particles. The bands at $1700-2010 \mathrm{~cm}^{-1}$ are assigned to bridging and multiply bonded CO on Pd ensembles comprising two or three contiguous Pd atoms [42,43]. With the incorporation of $\mathrm{Sb}$, the ratio of bridging and multiply bonded CO to linearly bonded CO increases gradually (Table 3). This suggests that the concentration of small Pd clusters increase with increasing Sb content leading to an increase in the number of low-coordinated $\mathrm{Pd}$ sites at the corners and edges. For $\mathrm{Pd}_{2} \mathrm{Sb}$, only linearly bonded $\mathrm{CO}$ is observed indicating that only highly dispersed clusters or

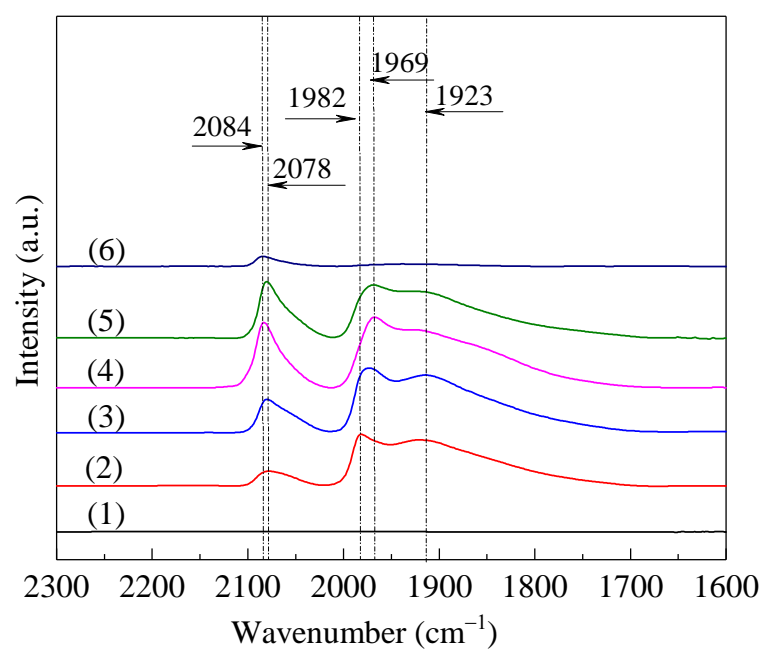

Fig. 6. In situ DRIFTS for CO adsorption over different catalysts at $283 \mathrm{~K}$ in stream of $\mathrm{Ar}$ (50 mL/min). (1) $\mathrm{Sb}$, (2) $\mathrm{Pd}$, (3) $\mathrm{Pd}_{80} \mathrm{Sb}$, (4) $\mathrm{Pd}_{50} \mathrm{Sb}$, (5) $\mathrm{Pd}_{20} \mathrm{Sb}$, (6) $\mathrm{Pd}_{2} \mathrm{Sb}$. isolated Pd atoms are formed. The results indicate that the proportion of contiguous Pd surface sites decreases and the number of single Pd sites increases due to the dilution effect of Sb. This change is responsible for the geometric effect produced by changing the relative Pd and Sb contents. A red shift of bridging CO bands from 1982 to $1969 \mathrm{~cm}^{-1}$ is observed in the presence of $\mathrm{Sb}$. It is attributed to enhancement of the $d$-orbital electron density of $\mathrm{Pd}$ by charge-transfer from $\mathrm{Sb}$ to $\mathrm{Pd}$, which produces strong electron back-donation to the $2 \pi^{*}$ molecular orbitals of CO [44]. A similar phenomenon has been observed for $\mathrm{Pd}-\mathrm{Au} / \mathrm{TiO}_{2}\left(\mathrm{SiO}_{2}\right)$ catalysts $[17,35]$.

Since the catalysts were under an $\mathrm{O}_{2}$-rich circumstance in the reaction, herein the effect of $\mathrm{O}_{2}$ on Pd surface was investigated by pretreating the samples with $\mathrm{O}_{2}$ for 30 min following the reduction process. Compared to the samples without $\mathrm{O}_{2}$ pretreatment (Fig. 6), the relative intensities of peaks for $\mathrm{O}_{2}$ pretreated catalysts changed remarkably, and a new peak at $2123 \mathrm{~cm}^{-1}$ was observed for $\mathrm{Pd}_{50} \mathrm{Sb}$ and $\mathrm{Pd}_{20} \mathrm{Sb}$ (Fig. 7). The changes in the peak positions and intensities probably stem from the geometric and electronic modification of Pd atoms with the adsorption of $\mathrm{O}_{2}$. The new peak at $2123 \mathrm{~cm}^{-1}$ can be attributed to the vibration mode of $\mathrm{CO}$ bonded on $\mathrm{Pd}^{\sigma+}$, which represents partially oxidized $\mathrm{Pd}$ formed via the pre-adsorption of $\mathrm{O}_{2}[45,46]$. Interestingly, the peak at $2123 \mathrm{~cm}^{-1}$ was not observed for pure Pd. It has been demonstrated that CO could not be adsorbed on bulk PdO at room temperature $[47,48]$. In comparison with the samples without pretreatment, the $\mathrm{O}_{2}$-pretreated $\mathrm{Pd}_{50} \mathrm{Sb}$ and $\mathrm{Pd}_{20} \mathrm{Sb}$ catalysts showed a reduction in the intensities of the linearly bonded CO; thus, we deduce

Table 3

Correlation of the intensities of CO-Pd in DRIFT spectra.

\begin{tabular}{lccc}
\hline \multirow{2}{*}{ Catalyst } & \multicolumn{3}{c}{ Calculation results of peak area from DRIFT spectra } \\
\cline { 2 - 4 } & $\begin{array}{c}\text { Peak 1 } \\
\left(2010-2115 \mathrm{~cm}^{-1}\right)\end{array}$ & $\begin{array}{c}\text { Peak 2 } \\
\left(2010-1700 \mathrm{~cm}^{-1}\right)\end{array}$ & $\begin{array}{c}\text { Peak 2 / } \\
\text { Peak 1 }\end{array}$ \\
\hline $\mathrm{Pd}_{2} \mathrm{Sb}$ & 1.91 & 1.46 & 0.76 \\
$\mathrm{Pd}_{20} \mathrm{Sb}$ & 12.13 & 43.71 & 3.60 \\
$\mathrm{Pd}_{50} \mathrm{Sb}$ & 13.72 & 57.70 & 4.21 \\
$\mathrm{Pd}_{80} \mathrm{Sb}$ & 8.09 & 54.01 & 6.68 \\
$\mathrm{Pd}$ & 3.77 & 44.13 & 11.72 \\
\hline
\end{tabular}




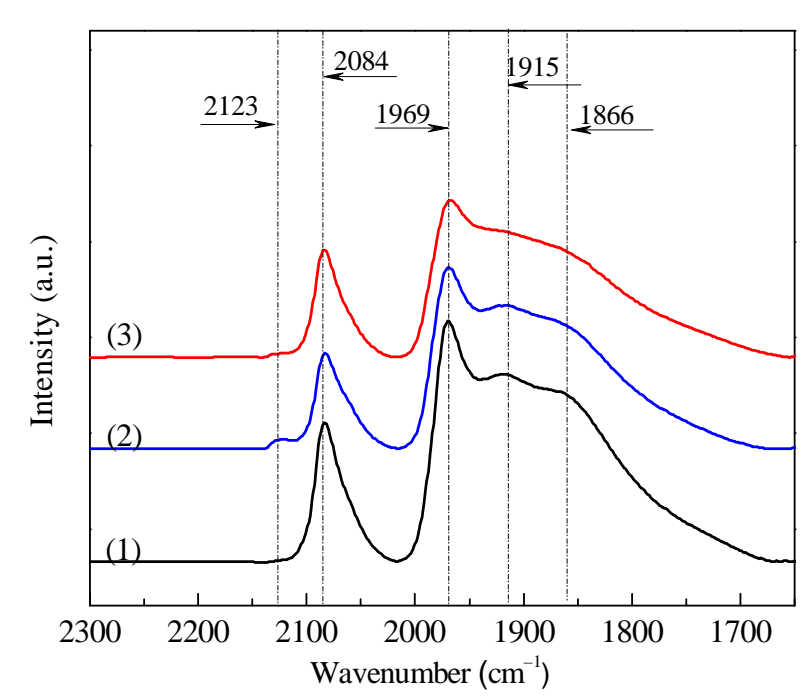

Fig. 7. In situ DRIFTS spectra for CO adsorption over catalysts pretreated with $\mathrm{O}_{2}$. (1) $\mathrm{Pd},(2) \mathrm{Pd}_{50} \mathrm{Sb}$, (3) $\mathrm{Pd}_{20} \mathrm{Sb}$.

that $\mathrm{O}_{2}$ prefers to adsorb at the corner or edge sites of $\mathrm{Pd}$. Moreover, from the change in the vibration mode of $\mathrm{CO}$ on contiguous ensembles, it can be inferred that $\mathrm{O}_{2}$ also existed on the plane sites of $\mathrm{Pd}$ particles. Thus, in comparison with the Pd-alone catalyst, the highly reactive sites for $\mathrm{O}_{2}$ dissociation at the corner or edge of Pd-Sb catalysts were significantly deactivated by pre-adsorbed $\mathrm{O}_{2}$, and the interaction between molecular $\mathrm{O}_{2}$ and $\mathrm{Pd}-\mathrm{Sb}$ catalysts weakened remarkably. Therefore, the addition of $\mathrm{Sb}$ is beneficial for the selective activation of $\mathrm{O}_{2}$ and subsequent $\mathrm{H}_{2} \mathrm{O}_{2}$ synthesis.

\subsection{4. $\mathrm{H}_{2} / \mathrm{O}_{2}-\mathrm{TPD}$}

$\mathrm{Sb}$ has been proved to be inert for the activation of $\mathrm{H}_{2}$ [36]. Therefore, the presence of $\mathrm{Sb}$ was expected to suppress $\mathrm{H}_{2}$ adsorption. Accordingly, $\mathrm{H}_{2}$-TPD was conducted for all $\mathrm{Pd}-\mathrm{Sb} / \mathrm{TiO}_{2}$ and Pd-alone catalysts (Fig. 8). For the Pd-alone sample, two peaks at 741 and $794 \mathrm{~K}$ were observed at room temperature. The peak at $794 \mathrm{~K}$ can be assigned to $\mathrm{H}_{2}$ from the

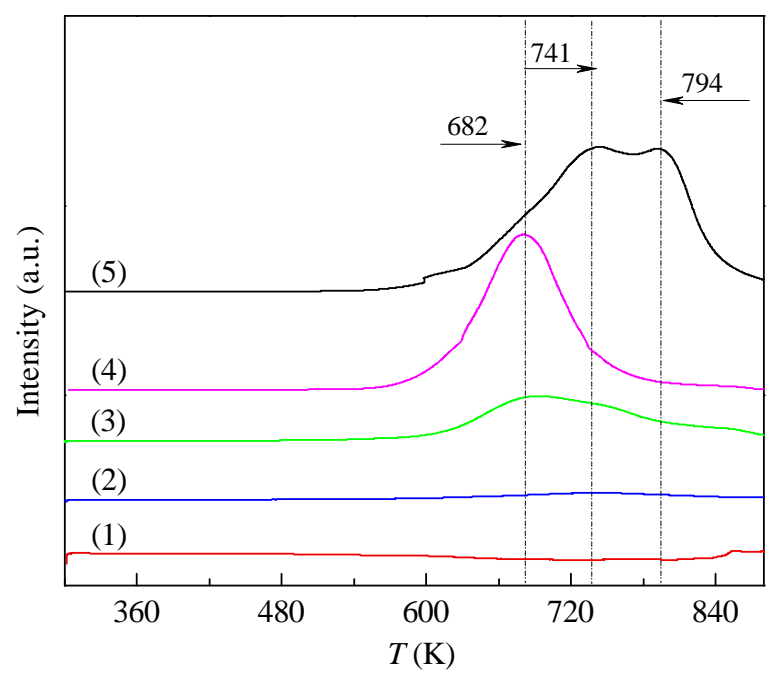

Fig. 8. $\mathrm{H}_{2}-\mathrm{TPD}$ profiles of $\mathrm{Pd}-\mathrm{Sb} / \mathrm{TiO}_{2}$ catalysts with different $\mathrm{Pd} / \mathrm{Sb}$ ratios. (1) Blank, (2) $\mathrm{Pd}_{2} \mathrm{Sb},(3) \mathrm{Pd}_{50} \mathrm{Sb}$, (4) $\mathrm{Pd} \mathrm{d}_{80} \mathrm{Sb}$, (5) Pd. recombination and desorption of sub-surface hydrogen species upon heating, and the one at $741 \mathrm{~K}$ can be attributed to the surface hydrogen species weakly bonded to the surface in the presence of sub-surface hydrogen species. Due to their small sizes in contrast to Pd crystals, hydrogen atoms can deeply migrate into the bulk far away from the surface, and thus, the sub-surface hydrogen species are available for the reaction. Upon heating the samples, surface hydrogen species were repopulated by the migration of hydrogen atoms from the sub-surface region [49-51]. With the increase in Sb loading, the peak shifted from 794 to $682 \mathrm{~K}$ gradually, and it disappeared completely for $\mathrm{Pd}_{2} \mathrm{Sb}$, indicating that the dilution of the surface $\mathrm{Pd}$ atoms with $\mathrm{Sb}$ suppressed the $\mathrm{H}_{2}$ adsorption and dissociation. It explains the great suppression effect of $\mathrm{Sb}$ on the hydrogenation of $\mathrm{H}_{2} \mathrm{O}_{2}$.

The dissociative activation of $\mathrm{O}_{2}$ is generally accepted to lead to the side reactions over Pd-based catalysts. $\mathrm{O}_{2}$-TPD profiles (Fig. S1) showed that the activation of $\mathrm{O}_{2}$ weakened in the presence of $\mathrm{Sb}$. No obvious $\mathrm{O}_{2}$ desorption was observed below $800 \mathrm{~K}$. The peak at $930 \mathrm{~K}$ can be attributed to atomic oxygen resulting from the decomposition of $\mathrm{PdO}_{x}$ [52-54]. With the increasing ratio of $\mathrm{Sb} / \mathrm{Pd}$, the atomic oxygen peak became weaker, owing to the weakness of $\mathrm{O}_{2}$ activation, suggesting that $\mathrm{Sb}$ species on the surface may inhibit the dissociative activation of $\mathrm{O}_{2}$ and oxidation of Pd. It agreed with the XPS results.

\subsection{Structure-performance relationship}

$\mathrm{H}_{2} \mathrm{O}_{2}$ is produced by the hydrogenation of molecular $\mathrm{O}_{2}$ on the Pd surface, whereas the sequential hydrogenation of $\mathrm{H}_{2} \mathrm{O}_{2}$ and the $\mathrm{O}-\mathrm{O}$ bond rupture of surface species would lead to the formation of $\mathrm{H}_{2} \mathrm{O}$ [55]. Tian et al. [56] has reported that the higher binding energy of $\mathrm{O}-\mathrm{O}$-containing surface species are not favorable for $\mathrm{H}_{2} \mathrm{O}_{2}$ synthesis because the higher $\mathrm{BE}$ results in lower dissociation barriers. The selectivity toward $\mathrm{H}_{2} \mathrm{O}_{2}$ is therefore mainly determined by the competition between $\mathrm{O}-\mathrm{H}$ bond formation and $\mathrm{O}-\mathrm{O}$ bond cleavage reactions of species containing 0-0 bonds. Density-functional theory (DFT) calculations demonstrated that low-coordinated Pd monomers embedded in $\mathrm{Au}$ sites were energetically unfavorable for the dissociation of $\mathrm{O}_{2}$ with a relative lower desorption $(<0.48 \mathrm{eV})$ and higher dissociation barrier $(>1.17 \mathrm{eV})$ than that of contiguous Pd ensembles [57]. Potentially, the isolated Pd sites, on which the $\mathrm{O}-\mathrm{O}$ bonds are more difficult to rupture, match the requirement of $\mathrm{H}_{2} \mathrm{O}_{2}$ formation better. In this work, Pd upon alloying with $\mathrm{Sb}$ can significantly enhance the $\mathrm{H}_{2} \mathrm{O}_{2}$ selectivity. To better understand the effect of the Sb promoter, the characterization results were thoroughly analyzed and a plausible mechanism was proposed.

As measured by TEM and XRD, Pd-Sb catalysts showed smaller particle sizes and higher Pd dispersion than the monometallic Pd samples. Hutchings et al. [58] reported that reducing the size of the Pd NPs led to more exposed Pd atoms and enhanced the activation of $\mathrm{H}_{2}$ and $\mathrm{O}_{2}$. However, $\mathrm{Pd}-\mathrm{Sb}$ catalysts in this work exhibited lower activity than monometallic Pd, and the catalysts with higher $\mathrm{Sb} / \mathrm{Pd}$ ratios $(>0.5)$ were inert for the formation of $\mathrm{H}_{2} \mathrm{O}_{2}$. It can be inferred that the incorporation of 
Sb remarkably changed the surface state of the Pd NPs. XPS results have proved that the surfaces of Pd-Sb catalysts were partially covered by $\mathrm{Sb}_{2} \mathrm{O}_{3}$ layers. In this case, few contiguous Pd ensembles are exposed to $\mathrm{H}_{2}$ and $\mathrm{O}_{2}$, retarding the activation of $\mathrm{H}_{2}$ and $\mathrm{O}_{2}$ and suppressing the catalyst activity. The BEs of the Pd $3 d$ core levels had a blue-shift of ca. $0.1-0.3 \mathrm{eV}$, indicating weak electronic interaction between $\mathrm{Sb}$ and $\mathrm{Pd}$. A similar shift was also reported in the Pt-Sb systems [59]. In addition, the ratio of $\mathrm{Pd}^{0} / \mathrm{Pd}^{2+}$ on the particle surface increased with an increase in the $\mathrm{Sb}$ concentration. Sb might inhibit the oxidation of Pd and weaken the metal-support interaction.

In situ DRIFT spectra revealed that the CO vibration mode over the fresh catalysts experienced an obvious change with the addition of $\mathrm{Sb}$. The fraction of the linear $\mathrm{CO}$ bands increased with the higher Sb loadings, indicating that $\mathrm{Sb}$ can generate more isolated Pd sites and reduce the contiguous Pd ensembles on the surface. Therefore, the non-dissociative activation of molecularly adsorbed $\mathrm{O}_{2}$ is pivotal for this reaction. Previous results have confirmed that isolated Pd sites surrounded by less active metal atoms showed lower activity for the dissociation of $\mathrm{O}-\mathrm{O}$ bonds, and they were more favorable for $\mathrm{H}_{2} \mathrm{O}_{2}$ formation than contiguous $\mathrm{Pd}$ ensembles [60]. Therefore, the higher $\mathrm{H}_{2} \mathrm{O}_{2}$ selectivity over Pd-Sb bimetallic catalysts could be attributed to the isolation effect of active Pd atoms by Sb. In contrast, the reason why the isolated Pd sites are unfavorable for the $\mathrm{O}-\mathrm{O}$ bond rupture is not yet clear for the reaction. Accordingly, in situ CO-DRIFTS over the $\mathrm{Pd}-\mathrm{Sb} / \mathrm{TiO}_{2}$ pretreated with $\mathrm{O}_{2}$ was performed to simulate the $\mathrm{O}_{2}$-rich environment in the reaction. Tian et al. [56] demonstrated that the addition of Te led to an increase in the low-coordinated active sites at the corner and edge sites, which are much more active for the undesired production of $\mathrm{H}_{2} \mathrm{O}$. The appearance of surface $\mathrm{Pd}^{\sigma+}$ species and the reduction of linearly bonded CO with the addition of $\mathrm{Sb}$ suggest that these low-coordinated active sites were partially oxidized by the $\mathrm{O}_{2}$ pretreatment, and their activities for $\mathrm{O}-\mathrm{O}$ bond scission reactions were suppressed. As a result, the $\mathrm{H}_{2} \mathrm{O}_{2}$ selectivities for the $\mathrm{Pd}-\mathrm{Sb}$ catalysts were enhanced.

As evidenced by TPD results, the addition of Sb suppressed the adsorption and dissociation of $\mathrm{H}_{2}$ and $\mathrm{O}_{2}$ over $\mathrm{Pd}$ catalysts, resulting in lower $\mathrm{H}_{2}$ conversions and higher $\mathrm{H}_{2} \mathrm{O}_{2}$ selectivities. Obviously, $\mathrm{Sb}$ hindered the hydrogenation and decomposition of $\mathrm{H}_{2} \mathrm{O}_{2}$ primarily by weakening the activation of $\mathrm{H}_{2}$ on $\mathrm{Pd}$. The weak adsorption of $\mathrm{O}_{2}$ at the $\mathrm{Pd}-\mathrm{Sb} / \mathrm{TiO}_{2}$ interface is proposed to enhance the selectivity of $\mathrm{H}_{2} \mathrm{O}_{2}$.

In summary, the catalyst structures were characterized using multiple techniques to identify the origin of active sites responsible for the observed high selectivity. The role of $\mathrm{Sb}$ on the active sites of Pd catalysts was investigated by: (1) isolating contiguous $\mathrm{Pd}$ sites via the formation of $\mathrm{Pd}-\mathrm{Sb}$ bimetallic sites, (2) coating Pd surface via the formation of $\mathrm{Sb}_{2} \mathrm{O}_{3}$ layer, and (3) promoting the formation of $\mathrm{Pd}^{\sigma+}$ species located on the surface during the reaction. Therefore, an optimum $\mathrm{Pd} / \mathrm{Sb}$ ratio should be finely tuned to obtain the best performance. A plausible mechanism for $\mathrm{H}_{2} \mathrm{O}_{2}$ synthesis was proposed as illustrated in Scheme 1. With the addition of Sb, Pd-Sb bimetallic sites were formed and Pd NPs were diluted, leading to the reduction of the $\mathrm{Pd}$ particle size. The isolated Pd sites surrounding by $\mathrm{Sb}$ are

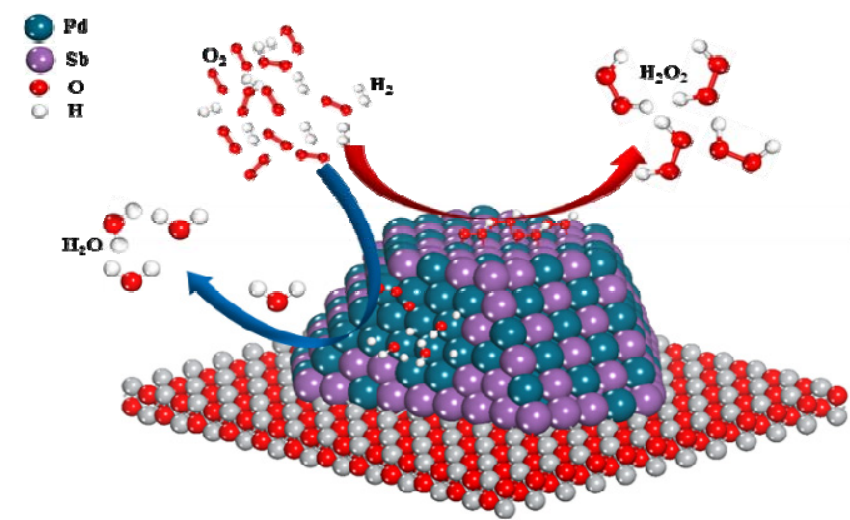

Scheme 1. Proposed mechanism for the direct synthesis of $\mathrm{H}_{2} \mathrm{O}_{2}$ over $\mathrm{Pd}-\mathrm{Sb} / \mathrm{TiO}_{2}$ catalysts.

responsible for the non-dissociative activation of $\mathrm{O}_{2}$ and selective synthesis of $\mathrm{H}_{2} \mathrm{O}_{2}$. In contrast, the contiguous $\mathrm{Pd}$ ensembles are more favorable for $\mathrm{H}_{2} \mathrm{O}$ formation because of their high activatity for the $\mathrm{O}-\mathrm{O}$ rupture reactions. $\mathrm{Sb}$, which is supposed to be concentrated on the catalyst surfaces, inhibited $\mathrm{H}_{2}$ adsorption and decreased the activity of $\mathrm{H}_{2} \mathrm{O}_{2}$ hydrogenation. However, due to the limitations of in situ characterizations in the tri-phase liquid system, the dynamic structures of Pd catalysts during the reaction and the mechanism of the effects of $\mathrm{Pd}^{\sigma+}$ species on the catalytic performance should be further investigated.

\section{Conclusions}

In this work, direct $\mathrm{H}_{2} \mathrm{O}_{2}$ synthesis from $\mathrm{H}_{2}$ and $\mathrm{O}_{2}$ has been studied using a series of bimetallic $\mathrm{Pd}-\mathrm{Sb} / \mathrm{TiO}_{2}$ catalysts with different $\mathrm{Pd} / \mathrm{Sb}$ ratios, among which the $\mathrm{Pd} \mathrm{d}_{50} \mathrm{Sb}$ catalyst exhibited the best performance with the $\mathrm{H}_{2} \mathrm{O}_{2}$ selectivity of $73 \%$. $\mathrm{H}_{2} \mathrm{O}_{2}$ hydrogenation rates decreased rapidly with the increase in the $\mathrm{Sb} / \mathrm{Pd}$ ratios. Multiple characterization results indicated that the electronic and geometric structures of $\mathrm{Pd}-\mathrm{Sb}$ catalysts were finely tuned with the $\mathrm{Sb}$ concentrations. In situ CO-DRIFT, XPS, and $\mathrm{H}_{2}$-TPD results proved that the increase in Sb concentration led to an increase in the ratio of isolated Pd sites that are assumed to be less active for side reactions and more favorable for $\mathrm{H}_{2} \mathrm{O}_{2}$ formation. In the meantime, the amount of contiguous $\mathrm{Pd}$ ensemble sites that are highly reactive for $\mathrm{H}_{2} \mathrm{O}_{2}$ hydrogenation were reduced, thus improving the selectivity. In summary, through adding a second nonprecious metal $\mathrm{Sb}$ to $\mathrm{Pd}$, the highly selective Pd-based bimetallic catalysts were obtained for $\mathrm{H}_{2} \mathrm{O}_{2}$ synthesis. Deep insight into the effect of $\mathrm{Sb}$ on Pd particles will have more implications for the understanding of the mechanism and rational design of Pd catalysts for $\mathrm{H}_{2} \mathrm{O}_{2}$ synthesis.

\section{References}

[1] G. Goor, J. Glenneberg, and S. Jacobi, in: Hydrogen Peroxide, Ullmann's Encyclopedia of Industrial Chemistry, Wiley-VCH Verlag GmbH \& Co. KGaA, 2000, 1-5.

[2] J. M. Campos-Martin, G. Blanco-Brieva, J. L. G. Fierro, Angew. Chem. 
Int. Ed., 2006, 45, 6962-6984.

[3] J. K. Edwards, S. J. Freakley, R. J. Lewis, J. C. Pritchard, G. J. Hutchings, Catal. Today, 2015, 248, 3-9.

[4] C. Samanta, Appl. Catal. A, 2008, 350, 133-149.

[5] R. Dittmeyer, J. D. Grunwaldt, A. Pashkova, Catal. Today, 2015, 248, 149-159.

[6] E. J. Beckman, Green Chem., 2003, 5, 332-336.

[7] J. H. Lunsford, J. Catal, 2003, 216, 455-460.

[8] Y. H. Yi, L. Wang, G. Li, H. C. Guo, Catal Sci. Technol, 2016, 6, 1593-1610.

[9] V. R. Choudhary, C. Samanta, J. Catal, 2006, 238, 28-38.

[10] V. R. Choudhary, C. Samanta, T. V. Choudhary, Appl. Catal A, 2006, 308, 128-133.

[11] S. Melada, R. Rioda, F. Menegazzo, F. Pinna, G. Strukul, J. Catal., 2006, 239, 422-430.

[12] J. Kim, Y. M. Chung, S. M. Kang, C. H. Choi, B. Y. Kim, Y. T. Kwon, T. J. Kim, S. H. Oh, C. S. Lee, ACS Catal, 2012, 2, 1042-1048.

[13] R. Arrigo, M. E. Schuster, S. Abate, S. Wrabetz, K. Amakawa, D. Teschner, M. Freni, G. Centi, S. Perathoner, M. Hävecker, R. Schlögl, ChemSusChem, 2014, 7, 179-194.

[14] G. M. Lari, B. Puértolas, M. Shahrokhi, N. López, J. Pérez-Ramírez, Angew. Chem., 2017, 56, 1775-1779.

[15] J. K. Edwards, B. Solsona, E. Ntainjua. N, A. F. Carley, A. A. Herzing, C. J. Kiely, G. J. Hutchings, Science, 2009, 323, 1037-1041.

[16] J. K. Edwards, J. Pritchard, L. Lu, M. Piccinini, G. Shaw, A. F. Carley, D. J. Morgan, C. J. Kiely, G. J. Hutchings, Angew. Chem. Int. Ed, 2014, 53, 2381-2384.

[17] L. K. Ouyang, G. J. Da, P. F. Tian, T. Y. Chen, G. D. Liang, J. Xu, Y. F. Han, J. Catal, 2014, 311, 129-136.

[18] S. J. Freakley, Q. He, J. H. Harrhy, L. Lu, D. A. Crole, D. J. Morgan, E. Ntainjua N, J. K. Edwards, A. F. Carley, A. Y. Borisevich, C. J. Kiely, G. J. Hutchings, Science, 2016, 351, 965-968.

[19] S. L Wang, K. G Gao, W. Li, J. L Zhang, Appl. Catal A, 2017, 531, 89-95.

[20] H. C. Ham, G. S. Hwang, J. Han, S. W. Nam, T. H. Lim, J. Phys. Chem. C, 2009, 113, 12943-12945.

[21] S. Maity, M. Eswaramoorthy, J. Mater. Chem. A, 2016, 4, 3233-3237.

[22] P. F. Tian, X.Y . Xu, C. Ao, D. D. Ding, W. Li, R. Si, W. Tu, J. Xu, Y. F. Han, ChemSusChem, 2017, 17, 3342-3346.

[23] P. F. Tian, L. K. Ouyang, X. Y. Xu, C. Ao, X. C. Xu, R. Si, X. J. Shen, M.
Lin, J. Xu, Y. F. Han, J. Catal, 2017, 349, 30-40.

[24] S. Gatla, O. Mathon, A. Rogalev, S. Pascarelli, J. Radnik, M. M. Pohl, A. Brückner, J. Phys. Chem. C, 2017, 121, 3854-3861.

[25] A. Benhmid, K. V. Narayana, A. Martin, B. Lucke, Chem. Commun., 2004, 2118-2119.

[26] S. Gatla, N. Madaan, J. Radnik, V. N. Kalevaru, M. M. Pohl, B. Lücke, A. Martin, A. Brückner, Appl Catal A, 2011, 398, 104-112.

[27] L. K. Ouyang, P. F. Tian, G. J. Da, X. C. Xu, C. Ao, T. Y. Chen, R. Si, J. Xu, Y. F. Han, J. Catal, 2015, 321, 70-80.

[28] E. Ntainjua N, M. Piccinini, J. C. Pritchard, J. K. Edwards, A. F. Carley, J. A. Moulijn, G. J. Hutchings, ChemSusChem, 2009, 2, 575-580.

[29] C. Ao, P. F. Tian, L. K. Ouyang, G. J. Da, X. Y. Xu, J. Xu, Y. F. Han, Catal. Sci. Technol, 2016, 6, 5060-5068.

[30] V. R. Choudhary, C. Samanta, T. V. Choudhary, J. Mol. Catal. A., 2006, 260, 115-120.

[31] E. H. Voogt, A. J. M. Mens, O. L. J. Gijzeman, J. W. Geus, Surf. Sci., 1997, 373, 210-220.

[32] F. P. Leisenberger, G. Koller, M. Sock, S. Surnev, M. G. Ramsey, F. P. Netzer, B. Klötzer, K. Hayek, Surf. Sci., 2000, 445, 380-393.

[33] M. Brun, A. Berthet, J. C. Bertolini, J. Electron. Spectrosc. Relat. Phenom., 1999, 104, 55-60.

[34] A. K. Datye, J. Bravo, T. R. Nelson, P. Atanasova, M. Lyubovsky, L. Pfefferle, Appl Catal A, 2000, 1, 179-196.

[35] Y. F. Han, Z. Y. Zhong, K. Ramesh, F. X. Chen, L. W. Chen, T. White, Q. Tay, S. N. Yaakub, Z. Wang, J. Phys. Chem. C, 2007, 111, 8410-8413.

[36] F. Garbassi, Surf. Interface Anal, 1980, 2, 165-169.

[37] T. A. Carlson, in: Photoelectron and Auger Spectroscopy, Springer, Boston, MA, 1975, 99-164.

[38] G. Martra, Appl Catal A, 2000, 200, 275-285.

[39] J. C. Dupin, D. Gonbeau, P. Vinatier, A. Levasseur, Phys.Chem. Chem. Phys., 2000, 2, 1319-1324.

[40] P. J. Berlowitz, C. H. F. Peden, D. W. Goodman, J. Phys. Chem., 1988, 92, 5213-5221.

[41] C. W. Yi, K. Luo, T. Wei, D. W. Goodman, J. Phys. Chem. B, 2005, 109, 18535-18540.

[42] F. Gao, Y. L. Wang, D. W. Goodman, J. Phys. Chem. C, 2009, 113, 14993-15000.

[43] F. Gao, Y. L. Wang, D. W. Goodman, J. Am. Chem. Soc., 2009, 131, 5734-5735.

\section{Graphical Abstract}

Chin. J. Catal., 2018, 39: 673-681 doi: 10.1016/S1872-2067(18)63031-1

Promotional effects of Sb on Pd-based catalysts for the direct synthesis of hydrogen peroxide at ambient pressure

Doudou Ding, Xingyan Xu, Pengfei Tian,Xianglin Liu, Jing Xu*, Yi-fan Han *

East China University of Science and Technology; Zhengzhou University

Highly selective $\mathrm{Pd}-\mathrm{Sb} / \mathrm{TiO}_{2}$ bimetallic catalysts for the direct synthesis of $\mathrm{H}_{2} \mathrm{O}_{2}$ were obtained, and the addition of $\mathrm{Sb}$ increased the isolated $\mathrm{Pd}$ sites, which are favorable for $\mathrm{H}_{2} \mathrm{O}_{2}$ formation.

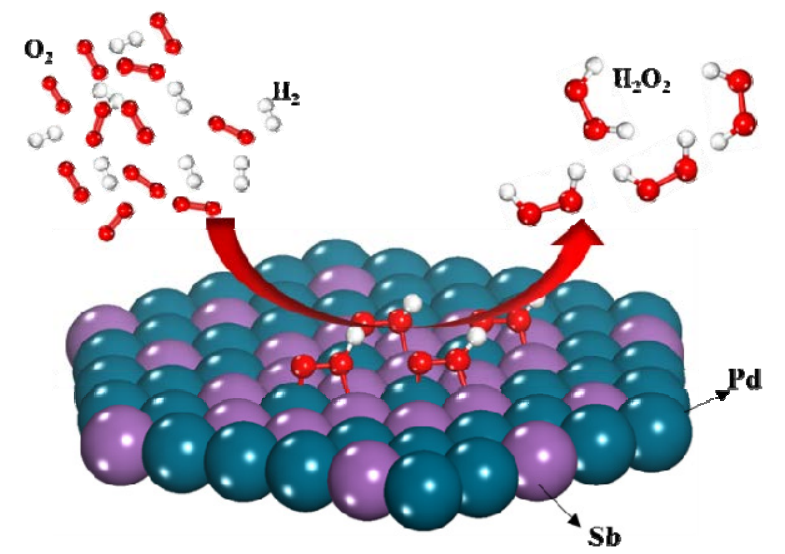


[44] P. Hu, D. A. King, M. H. Lee, M. C. Payne, Chem. Phys. Lett., 1995, 246, 73-78.

[45] M. Skotak, Z. Karpiński, W. Juszczyk, J. Pielaszek, L. Kẹpiński, D. V. Kazachkin, V. I. Kovalchuk, J. L. d'Itri, J. Catal, 2004, 227, 11-25.

[46] J. Xu, L. K. Ouyang, W. Mao, X. J. Yang, X. C. Xu, J. J. Su, T. Z. Zhuang, H. Li, Y. F. Han, ACS Catal, 2012, 2, 261-269.

[47] K. I. Hadjiivanov, G. N. Vayssilov, Adv. Catal., 2002, 47, 307-511.

[48] K. Zorn, S. Giorgio, E. Halwax, C. R. Henry, H. Grönbeck, G. Rupprechter, J. Phys. Chem. C, 2011, 115, 1103-1111.

[49] A. M. Doyle, S. K. Shaikhutdinov, S. D. Jackson, H. J. Freund, Angew. Chem. Int. Ed, 2003, 42, 5240-5243.

[50] M. Morkel, G. Rupprechter, H. J. Freund, Surf. Sci., 2005, 558, L209-L219.

[51] N. A. Khan, S. Shaikhutdinov, H. J. Freund, Catal Lett., 2006, 108, 159-164.

[52] X. C. Guo, A. Hoffman, J. T. Y. Jr., J. Chem. Phys., 1989, 90, 5787-5792.
[53] S. Penner, P. Bera, S. Pedersen, L. T. Ngo, J. J. W. Harris, C. T. Campbell, J. Phys. Chem. B, 2006, 110, 24577-24584.

[54] J. A. Hinojosa, H. H. Kan, J. F. Weaver, J. Phys. Chem. C, 2008, 112, 8324-8331.

[55] N. M. Wilson, D. W. Flaherty, J. Am. Chem. Soc., 2016, 138, 574-586.

[56] P. F. Tian, L. K Ouyang, X. C. Xu, J. Xu, Y. F. Han, Chin. J. Catal, 2013, 34, 1002-1012.

[57] D. W. Yuan, Z. R. Liu, Y. Xu, Phys. Lett. A, 2012, 376, 3432-3438.

[58] J. Pritchard, L. Kesavan, M. Piccinini, Q. He, R. Tiruvalam, N. Dimitratos, J. A. Lopez-Sanchez, A. F. Carley, J. K. Edwards, C. J. Kiely, G. J. Hutchings, Langmuir, 2010, 26, 16568-16577.

[59] R. F. Nie, D. Liang, L. Shen, J. Gao, P. Chen, Z. Y. Hou, Appl. Catal B, 2012, 127, 212-220.

[60] A. Plauck, E. E. Stangland, J. A. Dumesic, M. Mavrikakis, Proc. Natl. Acad. Sci., 2016, 113, E1973-E1982.

\title{
Sb 对 Pd 基催化剂用于常压直接合成 $\mathrm{H}_{2} \mathrm{O}_{2}$ 的促进效应
}

\author{
丁豆豆 ${ }^{\mathrm{a}}$, 徐兴奸 ${ }^{\mathrm{a}}$, 田鹏飞 ${ }^{\mathrm{a}}$, 刘向林 ${ }^{\mathrm{a}}$, 徐 晶 ${ }^{\mathrm{a},{ }^{*}}$, 韩一帆 ${ }^{\mathrm{a}, \mathrm{b}, \#}$ \\ a华东理工大学化学工程联合国家重点实验室, 上海200237 \\ $\mathrm{b}$ 郑州大学化工与能源学院多相催化工程科学研究中心, 河南郑州 450001
}

摘要: $\mathrm{H}_{2} \mathrm{O}_{2}$ 作为一种高效绿色氧化剂, 广泛应用于造纸、纺织、水处理等工业领域. 目前葱醌法是工业上生产 $\mathrm{H}_{2} \mathrm{O}_{2}$ 的主要 方法, 相比之下, 利用 $\mathrm{H}_{2}$ 和 $\mathrm{O}_{2}$ 直接合成 $\mathrm{H}_{2} \mathrm{O}_{2}$, 能耗低, 污染小, 适合与下游工艺技术进行耦合. 而缺乏高性能催化剂是制 约直接法合成 $\mathrm{H}_{2} \mathrm{O}_{2}$ 工业化的主要原因. 本文通过浸渍法制备了一系列负载型 $\mathrm{Pd}-\mathrm{Sb}_{2} / \mathrm{TiO}_{2}$ 双金属催化剂, 并用于常压下 $\mathrm{H}_{2} \mathrm{O}_{2}$ 直接催化合成反应. 利用透射电子显微镜 (TEM), $X$ 射线光电子能谱 (XPS), $\mathrm{H}_{2} / \mathrm{O}_{2}$ 程序升温脱附 $\left(\mathrm{H}_{2} / \mathrm{O}_{2}-\mathrm{TPD}\right.$ ), $\mathrm{X}$ 射线 衍射 (XRD), 原位 CO 吸附的傅里叶变换漫反射红外光谱 (CO-DRIFTS) 等手段对催化剂的电子和几何结构进行解析, 深 入研究了助剂 $\mathrm{Sb}$ 对该体系的促进作用.

结果显示, 与单金属 $\mathrm{Pd}$ 催化剂相比, 适量金属 $\mathrm{Sb}$ 的加入有效提高了催化性能, 抑制了副反应的发生. 当 $\mathrm{Pd} / \mathrm{Sb}$ 摩尔 比为 $50 / 1\left(\mathrm{Pd}_{50} \mathrm{Sb}\right)$ 时, $\mathrm{H}_{2} \mathrm{O}_{2}$ 的选择性高达 $73 \%$; 但是当 $\mathrm{Pd} / \mathrm{Sb}$ 为 2 时, 催化剂对生成 $\mathrm{H}_{2} \mathrm{O}_{2}$ 几乎没有活性. TEM 和 XRD 证 明, $\mathrm{Sb}$ 的加入显著促进了 $\mathrm{Pd}$ 颗粒在载体 $\mathrm{TiO}_{2}$ 上的分散. XPS 和 $\mathrm{H}_{2}-\mathrm{TPD}$ 实验, 发现, $\mathrm{Sb}$ 改变了催化剂表面 $\mathrm{Pd}^{2+} / \mathrm{Pd}^{0}$ 的比 例, 抑制了金属 $\mathrm{Pd}$ 的氧化; 同时, $\mathrm{Sb}$ 主要以氧化态存在, 在催化剂表面形成 $\mathrm{Sb}_{2} \mathrm{O}_{3}$ 氧化层, 覆盖表面的 $\mathrm{Pd}$ 活性位, 从而抑 制了反应中 $\mathrm{H}_{2}$ 在催化剂表面的活化以及 $\mathrm{H}_{2} \mathrm{O}_{2}$ 加氢副反应的发生. $\mathrm{O}_{2}$ - TPD 结果表明, 随着 $\mathrm{Sb}$ 的加入, $\mathrm{O}_{2}$ 的脱附峰明显减 弱, 表明 $\mathrm{Pd}-\mathrm{Sb} / \mathrm{TiO}_{2}$ 不利于 $\mathrm{O}_{2}$ 的解离吸附. 此外, 原位 CO-DRIFTS 实验结果表明, Sb 均匀分布在 Pd-Sb 催化剂表面, 致使 有利于生成 $\mathrm{H}_{2} \mathrm{O}$ 的连续 $\mathrm{Pd}$ 活性位明显减少, 而有利于合成 $\mathrm{H}_{2} \mathrm{O}_{2}$ 的单个 Pd 原子活性位明显增加.

总的来说, Sb 对 Pd 表面起到了显著的修饰作用, 提高了催化剂表面 $\mathrm{O}_{2}$ 的非解离活化, 从而促进了 $\mathrm{H}_{2} \mathrm{O}_{2}$ 的高选择性 合成. 但是过量 $\mathrm{Sb}$ 的加入会抑制催化剂对 $\mathrm{H}_{2}$ 的活化作用, 致使催化剂活性下降, 因此优选 $\mathrm{Pd} / \mathrm{Sb}$ 的比例对于提高催化剂 性能具有重要作用.

关键词: 双金属催化剂; 过氧化氢; 钯; 锑; 直接合成

收稿日期: 2017-11-30. 接受日期: 2018-01-10. 出版日期: 2018-04-05.

*通讯联系人. 电话: (021)64251938; 传真: (021)64251928; 电子信箱: xujing@ecust.edu.cn

\#通讯联系人. 电子信箱: yifanhan@ecust.edu.cn

基金来源：国家自然科学基金 (91534127, U1463205); 河南省中原学者; “111”引智计划 (B08021).

本文的电子版全文由Elsevier出版社在ScienceDirect上出版(http://www.sciencedirect.com/science/journal/18722067). 